\title{
Ultrastructural observations of ovulation in the Japanese . long-fingered bat, Miniopterus schreibersii fuliginosus
}

\author{
T. Mōri and T. A. Uchida \\ Zoological Laboratory, Faculty of Agriculture, Kyushu University, Fukuoka 812, Japan
}

\begin{abstract}
Summary. In the Japanese long-fingered bat, Miniopterus schreibersii fuliginosus, ovulation occurred spontaneously with the disappearance of the granulosa layer and germinal epithelium at the apex of the stigma which was formed simultaneously with expulsion of the first polar body, and with the subsequent bleeding from the capillary lumina of the theca interna. After ovulation the rupture point was plugged by luteinizing granulosa cells and overgrown by newly regenerated cells of the tunica albuginea and germinal epithelium.
\end{abstract}

\section{Introduction}

The long-fingered bat, Miniopterus schreibersii, of a genus which occurs only in the Old World, and of the subfamily Miniopterinae (family Vespertilionidae), has a unique reproductive pattern: autumn copulation in mid-October in the northern hemisphere (Courrier, 1924; Uchida, 1957) or in late May/early June in the southern hemisphere (Richardson, 1977; Wallace, 1978) is followed closely by ovulation and fertilization, and the single ovum discharged, always from the left ovary, remains in diapause in the right uterine horn during the winter. It has not yet been demonstrated, however, whether the ovulation occurs independently of a copulatory stimulus. Although Wimsatt (1944) provided a light microscope study of ovulation in the little brown bat, Myotis lucifugus lucifugus, detailed histological observations of ovulation in bats have been scanty. The present study was therefore carried out to determine whether the Japanese long-fingered bat ovulates spontaneously, and to examine the process of ovulation by electron microscopy.

\section{Materials and Methods}

To determine whether ovulation is spontaneous, 3 adult females were collected at Ohse-dō Cave $\left(32.5^{\circ} \mathrm{N}\right)$ in the Kumamoto Prefecture on 4 October 1980 and kept in captivity isolated from males until 16,17 and 19 October 1980 when they were killed. It was expected that these would be unmated females, and this was confirmed histologically. The reproductive organs were fixed in $10 \%$ formalin, embedded in paraffin wax, and stained with Delafield's haematoxylin and eosin for light microscopy. For the morphological study of follicular maturation and ovulation, 55 adult females were collected at Ibarayama abandoned mine $\left(33.5^{\circ} \mathrm{N}\right)$ in the Fukuoka Prefecture and Ohse-dō Cave in mid-October of 1970-1979; 46 females had not copulated, 2 had a vaginal plug, 2 were preovulatory with the follicle showing a stigma, 4 were postovulatory with an unfertilized tubal ovum and 1 contained a zygote. The reproductive organs were fixed in cold $3 \%$ glutaraldehyde in $0.2 \mathrm{M}$-phosphate buffer, $\mathrm{pH} 7 \cdot 2$, for $6 \mathrm{~h}$, then washed briefly in the same buffer and further fixed for $3 \mathrm{~h}$ in cold $1.3 \%$ osmium tetroxide buffered with the same buffer, dehydrated with acetone and embedded in Epon 812. Thin sections (about 
$60 \mathrm{~nm}$ ) for electron microscopy were cut with glass knives on a Porter-Blum Mt-2B microtome, doubly stained with uranyl and lead acetate, and examined with an Hitachi HS-9 electron microscope. Thick sections $(1.5 \mu \mathrm{m})$ were made on the same microtome, and stained with toluidine blue for light microscopy.

\section{Results}

Of the 3 unmated bats, ovulation had occurred spontaneously in the 2 killed on 16 and 19 October. Morphological changes of the follicle and ovarian surface just before or after ovulation are described separately according to the following four stages-copulatory, preovulatory, postovulatory and fertilizing stage.

\section{Copulatory stage}

At the mating season, although a large Graafian follicle (about $800 \mu \mathrm{m}$ ) was found only in the left ovary adjacent to its surface in unmated females (body wt $13.5 \mathrm{~g}$ ), there was no stigma. In females with a vaginal plug (a whitish-yellow, cheese-like plug measuring $2.0 \times 1.3 \mathrm{~mm}$ ), the

\section{PLATES 1-5}

Abbreviations: A, antrum; B, basement membrane; C, capillary; Ca, cell of tunica albuginea; $\mathrm{Cc}$, cell of corona radiata; $\mathrm{Cg}$, cell of germinal epithelium; $\mathrm{Ci}$, cell of theca interna; $\mathrm{Cp}$, cytoplasmic projection; D, detaching granulosa cell; E, erythrocytes; Em, extracellular matrix; En, endothelium; Er, endoplasmic reticulum; Es, extracellular space; F, first polar body; G, granule; Gc, granulosa cell; Ge, germinal epithelium; J, junctional complex; L, luteinizing cell; $\mathrm{M}$, mitochondrion; $\mathrm{Mi}$, microvilli; $\mathrm{O}$, oviduct; $\mathrm{Op}$, ovulation point; $\mathrm{Ot}$, oedematous tunica albuginea; P, primordial follicle; Ps, perivitelline space; S, stigma; T, theca interna; Ta, tunica albuginea; $U$, undersurface cytoplasmic extrusion; $Z$, zona pellucida.

\section{PLATE 1}

Fig. 1. Median section through a Graafian follicle about to rupture in the left ovary of a female with a vaginal plug, showing the undispersed appearance of the follicle cells.

Figs 2 and 3. The left ovary with a Graafian follicle just before rupture, showing the external appearance of the stigma (Fig. 2) and section across its apex (Fig. 3). Note the oedematous tunica albuginea and the extravasated blood in the rectangle.

Fig. 4. Electron micrograph showing the oedematous tunica albuginea and germinal epithelium of the same ovary as in Figs 2 and 3.

Fig. 5. Median section through the same Graafian follicle as in Figs 2 and 3, showing dispersion of the follicle cells and separation of the cumulus oophorus from the follicle wall. These phenomena are synchronized with expulsion of the first polar body (inset).

Figs 6 and 7. Apical portion of the stigma wall. Fig. 6. Light micrograph of the area enclosed in the rectangle on Fig. 3 at higher magnification, showing detaching granulosa cells and the punctate haemorrhage. Fig. 7. Electron micrograph of the portion near the apex of the stigma, showing components of the stigma wall. Note the disappearance of the theca externa.

\section{PLATE 2}

Figs 8 and 9. Electron micrographs of the non-detaching granulosa cells at the apex of the stigma in the rectangle on Fig. 3. Fig. 8. Small bleb-like cytoplasmic projections, containing only endoplasmic reticulum, expanding into the antrum. Fig. 9. Large and irregular-shaped undersurface cytoplasmic projections with various cell organelles invade the basement membrane.

Fig. 10. Electron micrograph of the follicle side of the punctate haemorrhage portion in the rectangle on Fig. 3, showing bleeding to the follicular antrum via passages within the broken granulosa layer and disappearance of the germinal epithelium. 
PLATE 1

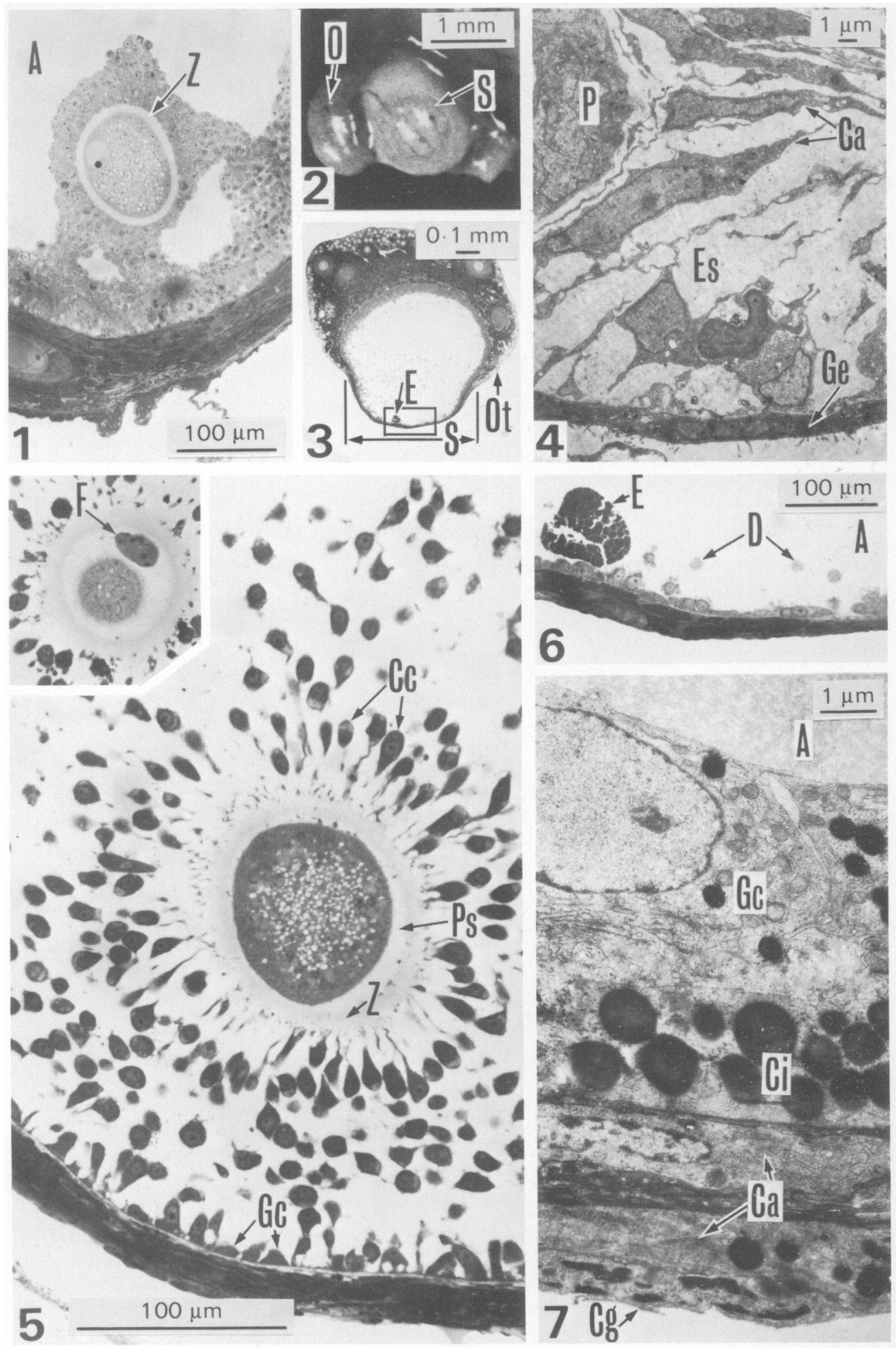

(Facing p. 392) 


\section{PLATE 2}
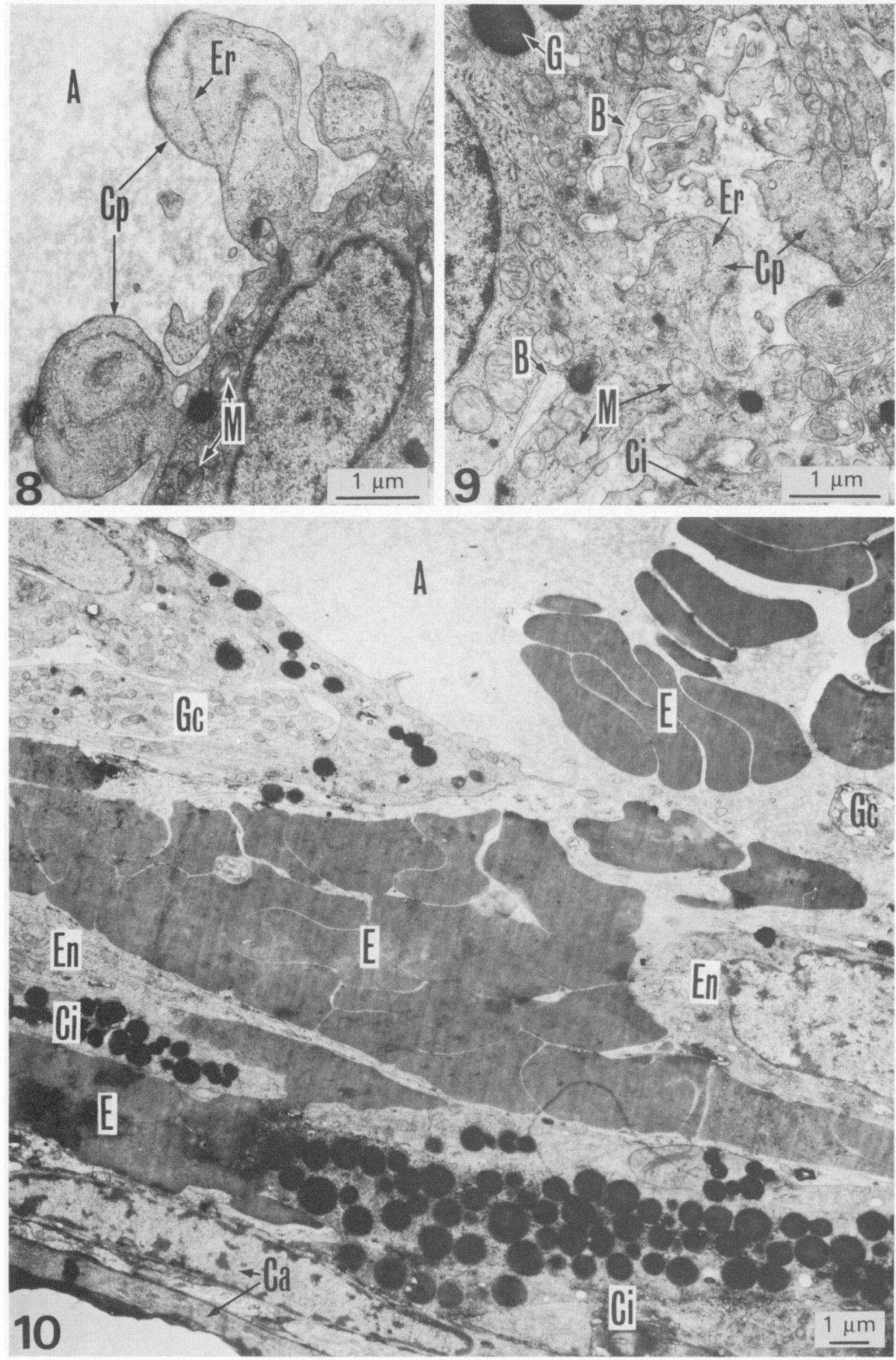


\section{PLATE 3}

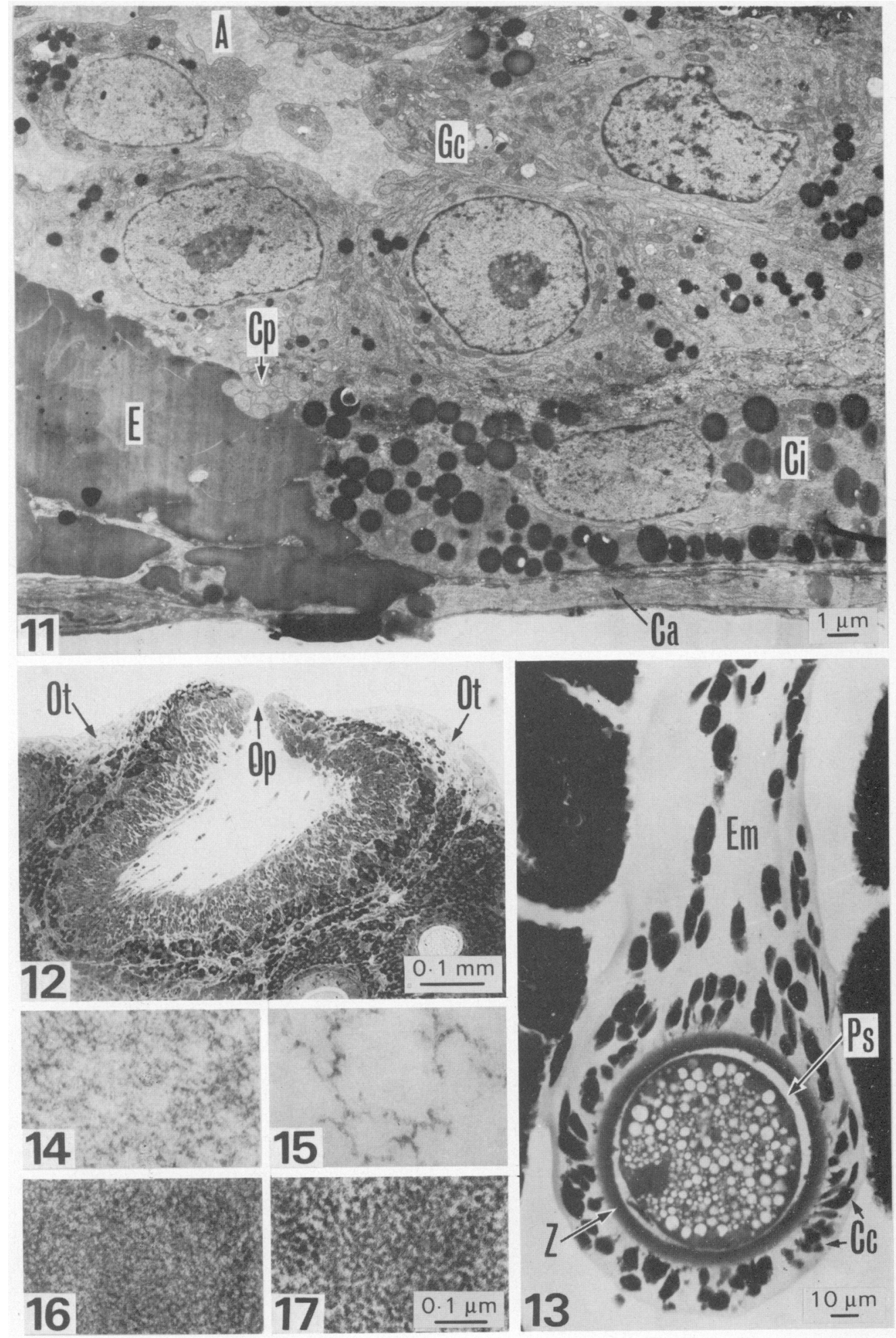


PLATE 4
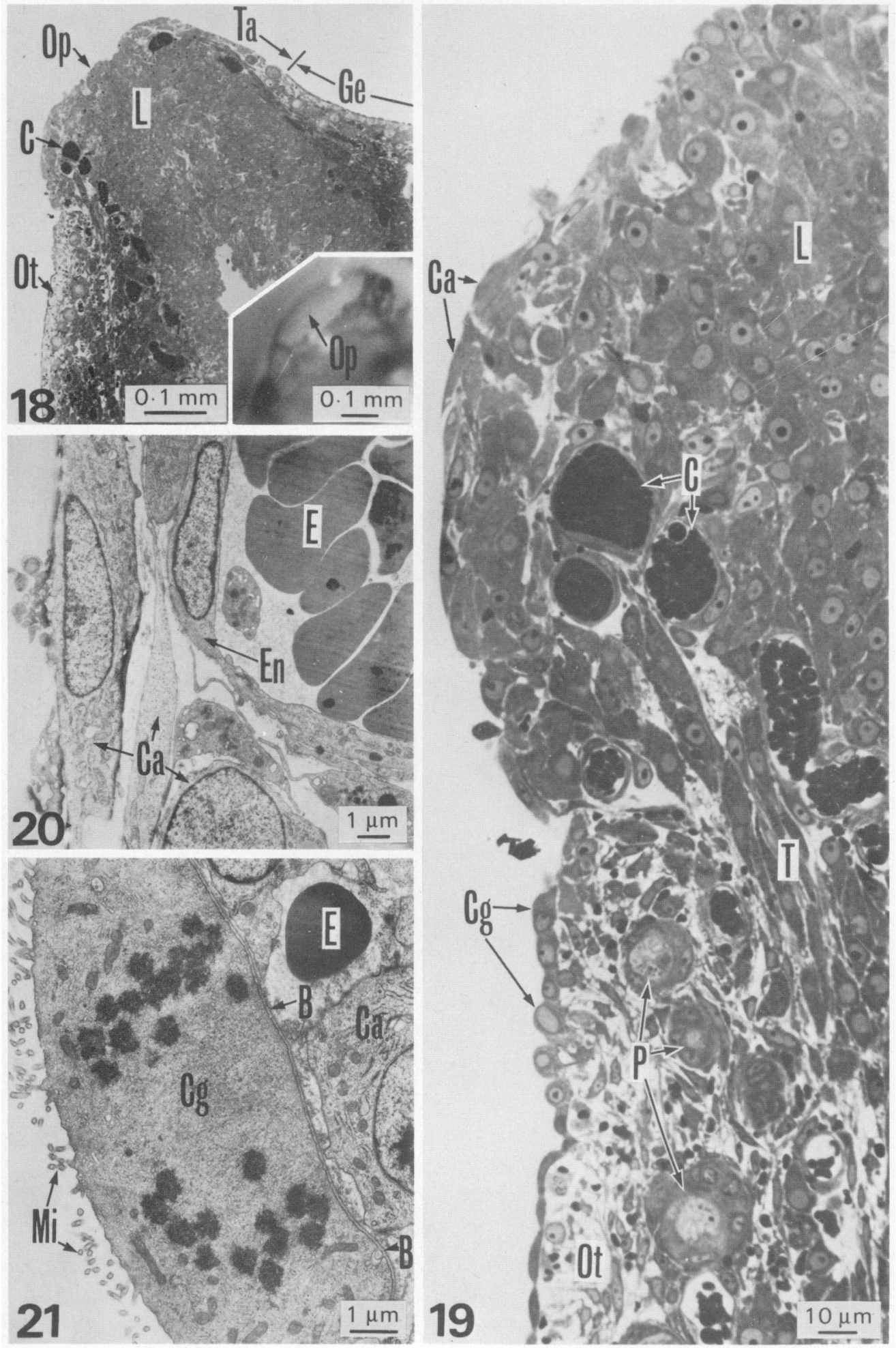


\section{PLATE 5}
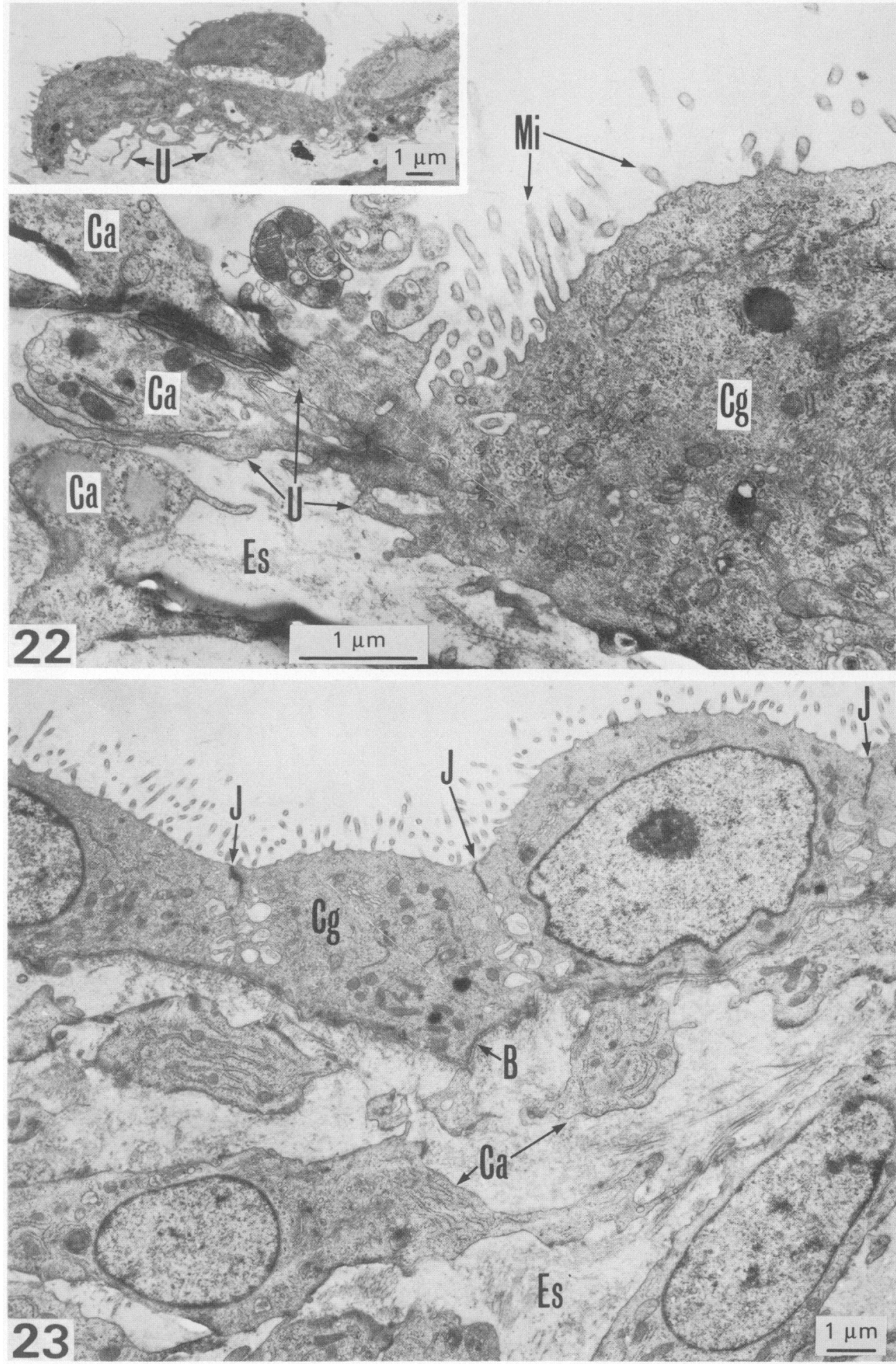
Graafian follicle was larger and closer to the ovarian surface. The ovum had a large ellipsoidal nucleus and a globular nucleolus, and the cumulus oophorus was joined to the granulosa layer by a cellular retinaculum. The cumulus cells were connected with one another by gap junctions and were not dispersed. The stigma had not formed (Pl. 1, Fig. 1).

\section{Preovulatory stage with the stigma}

The stigma was visible as a translucent area where the follicle bulged at the ovarian surface through the distended and weakened oedematous tunica albuginea (Pl. 1, Figs 2, 3, and 4). In addition, gap junctional contacts amongst the granulosa cells and the cumulus cells had disappeared and these cells were dispersed. The cumulus oophorus became entirely freed in the antrum while cells of the corona radiata remained attached to the zona pellucida by one or two slender cytoplasmic processes (Pl. 1, Fig. 5). These phenomena were synchronized with expulsion of the first polar body (P1. 1, Fig. 5, inset).

In the apical portion of the stigma, the majority of granulosa cells became detached from the granulosa layer and migrated into the antrum (Pl. 1, Fig. 6), the granulosa layer in this portion thereby becoming thinner than in the basal part (Pl. 1, Fig. 3). At the same time, the theca externa near the apex of the stigma disappeared. The ovarian follicle wall at this point therefore consisted of 4 layers, i.e. germinal epithelium, tunica albuginea, theca interna and a granulosa layer, from the outside inwards (Pl. 1, Fig. 7).

On the free surface of the granulosa cells detaching into the antrum or remaining on the basement membrane, small bleb-like cytoplasmic projections including only endoplasmic reticulum were recognized (Pl. 2, Fig. 8). Large and irregular-shaped undersurface cytoplasmic projections expanded from the attached granulosa cells into the theca interna through the partly fragmented basement membrane, and were characterized by their contained mitochondria, small granules and microtubules besides endoplasmic reticulum (P1. 2, Fig. 9).

\section{PLATE 3}

Fig. 11. Electron micrograph of the ovarian surface side of the haemorrhage portion in the rectangle on Fig. 3, showing leakage of the erythrocytes to the ovarian surface via passages devoid of the theca interna, tunica albuginea and germinal epithelium.

Figs 12 and 13. Sections showing the ovulation point of a ruptured follicle (Fig. 12) and an unfertilized ovum discharged from it (Fig. 13).

Figs 14-17. Electron micrographs of the matrix of the perivitelline space (Figs 14 and 15) and the substance of the zona pellucida (Figs 16 and 17) just before and after ovulation, respectively.

\section{PLATE 4}

Figs 18 and 19. A ruptured follicle in the process of repair. Fig. 18. Section across the ovulation point and its external appearance (inset). Fig. 19. Section of the same ovulation point as in Fig. 18 at higher magnification, showing regeneration of the tunica albuginea and germinal epithelium.

Fig. 20. Electron micrograph showing newly regenerated cells of the tunica albuginea.

Fig. 21. Electron micrograph of a proliferating original cell (anaphase) of the germinal epithelium, showing the presence of many microvilli on the free surface.

\section{PLATE 5}

Fig. 22. Electron micrograph of a cell at the tip of the newly regenerated germinal epithelium, showing the presence of many stout and branched undersurface cytoplasmic extrusions as compared with the microvilli on the free surface and lack of the basement membrane, and the whole feature at lower magnification (inset).

Fig. 23. Electron micrograph of young but settled cells of the germinal epithelium, showing the appearance of the junctional complexes and the basement membrane. 
At the apex of the stigma, the endothelia of blood capillaries in the theca interna became very thin and much dilated, with the development of fenestrations. Erythrocytes which flowed from the capillary lumina passed through the intercellular spaces of the theca interna, and then leaked into the follicular antrum via free passages where the granulosa layer and its basement membrane had disappeared (Pl. 2, Fig. 10) or through the tunica albuginea and onto the ovarian surface via passages devoid of the germinal epithelium and its basement membrane (Pl. 3, Fig. 11).

\section{Postovulatory stage with an unfertilized tubal ovum}

After rupture of the follicle a few granulosa cells were left at the ovulation point ( $\mathrm{Pl}$. 3, Fig. 12). Just after ovulation, the cytoplasmic processes of the corona radiata cells shortened and gap junctional contacts among the cells again became recognizable so that the cells exhibited an aggregated appearance. The corona cells were completely coated by an extracellular matrix ( $\mathrm{Pl}$. 3, Fig. 13). After ovulation the fine fuzz-like substance filling the perivitelline space before ovulation (Pl. 3, Fig. 14) changed to a rough filamentous substance (Pl. 3, Fig. 15), and the fine granular matrix of the zona pellucida (Pl. 3, Fig. 16) became a rough granular substance (Pl. 3, Fig. 17) with an increased affinity for toluidine blue (see Pl. 1, Fig. 5; Pl. 3, Fig. 13).

\section{Fertilizing stage}

The fertilizing stage was when a spermatozoon was binding to the egg plasma membrane. The ovulation point had begun to heal (Pl. 4, Fig. 18 and inset) by obliteration of the original opening with luteinizing granulosa cells, and then a covering with rejuvenated cells of the tunica albuginea (Pl. 4, Figs 19 and 20). At the same time, the remaining and flattened original cells with a few microvilli of the germinal epithelium proliferated vigorously to produce new cuboidal cells with numerous microvilli (Pl. 4, Figs 19 and 21). A few new cells situated at the tip of the newly formed germinal epithelium were devoid of basement membrane, but had many stout and branched cytoplasmic extrusions extending along the surface of the tunica albuginea (Pl. 5, Fig. 22 and inset) and also proliferative ability. New settled cells did not have these cytoplasmic extrusions but gave rise to the basement membrane and junctional complexes adjacent to the free surface on the cell boundaries among them (Pl. 5, Fig. 23).

\section{Discussion}

Sluiter \& Bels (1951) first discussed the problem of whether ovulation in bats was spontaneous and reported that hibernating Myotis myotis and $M$. emarginatus ovulated spontaneously. Pearson, Koford \& Pearson (1952), however, suggested that follicular maturation in hibernating Plecotus townsendii [Corynorhinus rafinesquei intermedius] might be due to a copulatory stimulus. On the other hand, Wimsatt \& Kallen (1957) stated that follicular maturation, and presumably ovulation, could occur spontaneously in hibernating Myotis lucifugus lucifugus, and Medway (1972) suggested that ovulation occurs spontaneously after an endogenously controlled period of oestrus in non-hibernating Tylonycteris pachypus and T. robustula. All the above-mentioned bats have the striking reproductive peculiarities of follicle survival and sperm storage, i.e. a long period from copulation in autumn to ovulation in spring. We consider that ovulation in the Japanese long-fingered bat, Miniopterus schreibersii fuliginosus, is probably spontaneous although copulation is followed closely by ovulation in this bat. Our observations on the changes in the Graafian follicle before ovulation and repair of the ovulation point in this bat are similar to those made by Wimsatt (1944) for M. l. lucifugus. The details on the repair of the tunica albuginea and germinal epithelium are confirmed.

In the long-fingered bat the stigma was formed just after appearance of the oedematous 
tunica albuginea, and the granulosa layer disappeared in its apical portion. Two factors, i.e. detachment of the granulosa cells (Parr, 1974) and fragmentation of the basement membrane which seems to be induced by the action of cytoplasmic projections (Byskov, 1969; Lipner, 1973; Bjersing \& Cajander, 1974a; Abel, Verhage, McClellan \& Niswender, 1975), appear to be involved in the disappearance of the granulosa layer. The granulosa cell projections invading the theca interna probably play a part in its fragmentation.

The passage of erythrocytes through intercellular spaces of the theca interna, and into the follicular antrum or onto the ovarian surface suggests increased permeability of capillaries (Espey, 1974; Parr, 1974; Bjersing \& Cajander, 1974b), and an involvement of vascular changes in the process of ovulation in this bat.

We thank Professor E. W. Jameson, Jr, University of California, for comments on the manuscript.

\section{References}

Abel, J.H. Jr, Verhage, H.G., McClellan, M.C. \& Niswender, G.N. (1975) Ultrastructural analysis of the granulosa-luteal cell transition in the ovary of the dog. Cell Tiss. Res. 160, 155-176.

Bjersing, L. \& Cajander, S. (1974a) Ovulation and the mechanism of follicle rupture. V. Ultrastructure of tunica albuginea and theca externa of rabbit Graafian follicles prior to induced ovulation. Cell Tiss. Res. 153, 15-30.

Bjersing, L. \& Cajander, S. (1974b) Ovulation and the mechanism of follicle rupture. VI. Ultrastructure of theca interna and the inner vascular network, surrounding rabbit Graafian follicles prior to induced ovulation. Cell Tiss. Res. 153, 31-44.

Byskov, A.G. (1969) Ultrastructural studies on the preovulatory follicle in the mouse ovary. $Z$. Zellforsch. Mikrosk. Anat. 100, 285-299.

Courrier, R. (1924) Le cycle sexuel chez la femelle des Mammifères. Étude de la phase folliculaire. Archs Biol. 34, 369-477.

Espey, L.L. (1974) Ovarian proteolytic enzymes and ovulation. Biol. Reprod. 10, 216-235.

Lipner, H. (1973) Mechanism of mammalian ovulation. In Handbook of Physiology; Endocrinology, II, pp. 409-437. Eds R. O. Greep \& E. B. Astwood. American Physiological Society, Washington, D.C.

Medway, Lord (1972) Reproductive cycles of the flat-headed bats Tylonycteris pachypus and $T$. robustula (Chiroptera: Vespertilioninae) in a humid equatorial environment. Zool. J. Linn. Soc. 51 , 33-61.
Parr, E.L. (1974) Histological examination of the rat ovarian follicle wall prior to ovulation. Biol. Reprod. $11,483-503$.

Pearson, O.P., Koford, M.R. \& Pearson, A.K. (1952) Reproduction of the lump-nosed bat (Corynorhinus rafinesquei) in California. J. Mammal. 33, 273320.

Richardson, E.G. (1977) The biology and evolution of the reproductive cycle of Miniopterus schreibersii and $M$. australis (Chiroptera: Vespertilionidae). $J$. Zool., Lond. 183, 353-375.

Sluiter, J.W. \& Bels, L. (1951) Follicular growth and spontaneous ovulation in captive bats during the hibernation period. Proc. K. Ned. Akad. Wet., Ser. C 54, 585-593.

Uchida, T.A. (1957) Fertilization and hibernation in bats. Heredity, Tokyo 11, 14-17. [In Japanese.]

Wallace, G.I. (1978) A histological study of the early stages of pregnancy in the bent-winged bat (Miniopterus schreibersii) in north-eastern New South Wales, Australia $\left(30^{\circ} 27^{\prime} \mathrm{S}\right)$. J. Zool., Lond. 185, 519-537.

Wimsatt, W.A. (1944) Growth of the ovarian follicle and ovulation in Myotis lucifugus lucifugus. Am. J. Anat. 74, 129-173.

Wimsatt, W.A. \& Kallen, F.C. (1957) The unique maturation response of the Graafian follicles of hibernating vespertilionid bats and the question of its significance. Anat. Rec. 129, 115-131.

Received 30 December 1980 